\title{
The Mediating Impact of Psychological Capital and Job Relevant Information on the Influence of Budget Participation against Job Performance
}

\author{
Ikhlas UI Aqmal*, Noorlailie Soewarno \\ Faculty of Economics and Business, Airlangga University, Jl. Airlangga, No.4, Surabaya, Indonesia \\ *Corresponding Author: IkhlasUl Aqmal, Faculty of Economics and Business, Airlangga University, Jl. \\ Airlangga, No.4, Surabaya, Indonesia
}

\begin{abstract}
The purpose of this study was to investigate the mediating impact of psychological capital and job relevant information on the budget participation to job performance at the public sector managers in the provincial government of East Java. Data analyzed using SEM-PLS. The SEM-PLS allows the examination of the direct effects of budget participation on job performance and the indirect effects between budget participation and job performance that run through psychological capital and job relevant information. The findings of this study are that psychological capital fully mediates influence of budget participation to job performance, job relevant information fully mediates influence of budget participation to job performance. Limitations of this study are using questionnaire media to obtain primary data so that it relies on the level of respondent perception so that the subjectivity factor can be contained in it. Second limitation is generalizability of samples. Despite its limitations, this study has both academic and practical implications. The study adds to the job performance literature in a public sector organizations. The study also finds that manager's job performance can be improved by minimizing Psycap and JRI. Future research should study other mediation variables on the effect of budget participation on job performance.
\end{abstract}

Keywords: Job Performance, Psychological Capital, Job Relevant Information, Mediating, WarpPLS.

\section{INTRODUCTION}

Participation in a wider context is a process which members of the organization take part and have an influence in decision-making relating to them (Karsam, 2015). Participation in the context of the preparation of the budget is a process which individuals were involved and have influence in the preparation of budget targets, evaluating performance, and awarded based on the achievement of budget (Brownell, 1982). The involvement of someone in the preparation of the budget will tend to encourage them to understand the budget and will facilitate the achievement of budget goals (Anthony and Govindarajan, 2007). Managerial performance itself is judged based on how effective and efficient managers work to achieve the goals of the company (Stoner and Freeman, 1992). The organization allows employees to participate in the budgeting process, but do not always achieve a positive result against increasing performance (Kren, 1992; Covaleski et al., 2003; Heath and Brown, 2007). The researchers chose to remain maintain the idea that engagement employees in the preparation process budgets must positively affect their performance (Venkatesh and Blaskovich, 2012), and has been associated with no empirical results consistent, with deficiencies in the framework theoretical adopted by previous research (Chong and Chong, 2002; Covaleski et al., 2003).

The different study results are not universally conclusive can be solved with a contingency approach (Govindarajan, 1986). This approach provides an idea that the nature of the existing relationships in budget participation with managerial performance may differ from one situation to another. This approach is carried out in order to systematically evaluate various conditions other variables that can influence a relationship between the variables studied.

Therefore, psychology-based researchers have proposed a variable intervention model, which shows that there is interference from the individual's mental state between budget and performance (Covaleskietal., 2003). It cannot be denied that in this budgeting process involves the role of humans. The role in which human psychic conditions have a major effect on performance in the 
end. The psychological condition itself is referred to as psychological capital which can be interpreted as psychological capital or a kind of human capital attitude and behavior that plays a major role in determining success (Luthanset al., 2008).

Budgetary participation also provides an information function where lower level management can collect, exchange, and disseminate job relevant information(JRI), which aims to facilitate the managerial decision-making process and communicate information held to organizational decision makers (Kren,1992). Lower levels are allowed to participate in the budget-setting process managed to reveal their private information that is useful to plan budgets more realistically and accurate, especially the information that is related to work. Job relevant information can improve performance, because it provides accurate predictions of the state of the environment and also provides input in selecting appropriate actions (Chong and Chong, 2002; Sinuraya 2009).

Motivated by the results of previous studies, this study wants to confirm whether the psychological capital and job relevant information variables can mediate the influence of budget participation on job performance. The difference between this study and previous studies is two mediating variables were used simultaneously which have never been used in the influence of budget participation on job performance. The use of these two variables is intended to confirm the contingency theory through psychological capital and job relevant information as contingent factors that mediate the influence of budget participation on job performance. If previous research was carried out on various types of organizations, this research was carried out on one type of organization namely public-sector organizations where respondents in this study were echelon II and III structural officials in the East Java Province Regional Apparatus. Public sector organizations, particularly government, require a measurement model for the relationship of budget participation to performance, and this research is based on the idea that the need for research in the public sector, especially government in the nonfinancial sector for behavioral fields. In addition, public sector organizations are actively involved in budget preparation, and their performance-based budgeting.

Research in the field of public sector budgeting is very important, because it involves services to the public at large. Therefore, the structure and mechanism of budgeting must be designed to create good psychological capital and job relevant information so that ultimately creates positive managerial performance. The selection of East Java Province is based on the achievements of the East Java Provincial Government which received an award from the President in 2017 as the highest national best performing province. This is based on the Presidential Decree Number 38/TK/2017 concerning the awarding of honors Parasamya PurnaKarya Nugraha. The Central Government assesses that the East Java Provincial Government has successfully organized regional government based on the Regional Government Implementation Report (LPPD) in 2015. On the other hand, the Bhirawa Daily dated $11^{\text {th }}$ December 2017 reported that the realization of the East Java Provincial Government's Revenue Budget (APBD) absorption per $8^{\text {th }}$ December 2017 is only 81.45 percent even though the previous year's budget absorption is around 94 to 95 percent. Achievement of budget absorption as in previous years when approaching the close of the book, this indicates that planning is not good because the program piles up at the end of the period, new regional device organizations are competing to spend each other's budgets. The implementation of the program at the end of this period caused the quality of the program to be ignored because the measure of success was only limited to the implementation of the program without considering quality. This description of conditions in East Java Province shows that there is still a need for improvement in planning and budgeting so that regional funds can be allocated appropriately to the interests and welfare of the community.

\section{THEORETICAL REVIEW AND HyPotheSis DEVELOPMENT}

The first theory that became the basis of this research was the theory of goal setting. Goal setting theory states that goal setting affects a person's performance (Locke and Bryan, 1968). People performance who participate in formulating goals better than those who do not participate (Locke and Latham, 2002). The theory of goal setting is the basis of the relationship between budget participation and job performance, where the higher the level of budget participation will increase budget participation.

The next theory which is the basis of this research is contingency theory. Contingency theory is an approach to studying organizational behavior where explanations given as contingent factors such as technology, culture and the external environment influence the design and function of an organization. 
The premise of this theory is that there is no control system that is universally always appropriate to be applied to all organizations in every situation. In each organization there is a difference in the control system based on organizational and situational factors. Sisaye (1998) states that contingency theory is a contingent control system design on the situation of the organization where the control system will operate. The approach used in this study is intended to evaluate the participatory relationship between budget preparation and the performance of local government officials. The contingent factors chosen are psychological capital and job relevant information. Psychological capital of a person becomes the main capital to build positive behavior in working to improve managerial performance. Job relevant information can improve performance, because it provides accurate predictions of the state of the environment and also provides input in selecting appropriate actions.

\section{Budget Participation, Psychological Capital, Job Performance}

The manager involved in the budget arrangement will have an influence on budget preparation and then its performance will be evaluated in its achievement (Brownell, 1982). Research conducted by Nouri and Parker (1998), Indarto and Ayu (2011), Abata (2014), Oluwalope and Sunday (2017) shows that budgetary participation has a positive influence on managerial performance. Ulupui (2005) found that budgetary participation has a positive effect on managerial performance. The higher the degree of involvement in the budget preparation process, the higher the managerial performance will be generated. Milani's (1975) research, Sinuraya (2009), Syahputra (2014), showed different results, namely budget participation had no effect on managerial performance. A research conducted by Venkatesh and Blaskovich(2012) also found that budgetary participation did not have a direct influence on managerial performance. There are other variables that allegedly mediate this relationship.

Someone who is involved in the budgeting process will try his best to develop his potential to achieve the stated goals (Venkatesh and Blaskovich, 2012). In a research (Venkatesh and Blaskovich, 2012) it was found that the high level of budgetary participation was associated with a higher level of psychological capital. Managers involved in preparing the company's budget, will encourage managers to be able to develop themselves so as to increase self-potential. Nuryani et al. (2018), Lina (2015), Solehaet al. (2014) found evidence that budget participation has an effect on psychological capital.

Durrah et al. (2016), Falah (2018), Saithong-in and Ussahawanitchakit (2016), Luthanset al. (2005), (Liwarto and Kurniawan, 2015) found evidence that psychological capital affects direct manager performance. Kappagodaet al. (2014), found evidence that psychological capital of employees was significantly and positively correlated with manager performance. Luthans et al. (2008) provides evidence of the important role played by psychological capital in positively influencing employee performance. The study shows that the high level of psychological capital of employees contributes to improved performance.

Ulfaet al. (2017) found that the direct effect of budget participation on managerial performance was smaller than the indirect effect of psychological capital as a mediating variable. This shows that psychological capital can be mediation between budget participation variables and managerial performance because it can increase the influence of budget participation on managerial performance. Venkatesh and Blaskovich (2012) conducted a study using psychological capital as a mediating variable in the relationship between budget participation and performance. The results of the study, namely psychological capital mediate the relationship of budget participation and managerial performance. From this explanation, the hypothesis that can be taken is:

H1: psychological capital mediates the effect of budget participation on job performance.

\section{Budget Participation, Job Relevant Information, Job Performance}

Researches by Brownell and McInnes (1986), Hariyanti et al. (2015), Ulupui (2005), Karsam (2013), Setyarini and Susty (2014) show that participation in budgeting and managerial performance has a positive relationship. Abata (2014) found that budgetary participation has a positive effect on managerial performance. High budgeting coordination, the resulting managerial performance is also higher. Research by Brownell and Hirst (1986), Syahputra (2014), Medhayanti and Suardana (2015), showed different results, namely budget participation had no influence on managerial performance. 
Likewise, with Kren's research (1992) found that budgetary participation is not directly related to managerial performance. It is suspected that there are other variables that mediate the relationship.

Nengsyet al. (2013), Pongawa and Devie (2013), Lau and Tan (2003), Sinuraya (2009), Eker (2008), Surya and Devie (2013) show that budget participation influences job relevant information. Heath and Brown (2007) conducted research on employees involved in the budgeting process in various industries in the United States. The results show that the greater the level of budget participation, the greater the job relevant information that is owned by employees.

Lopez et al. (2009) found a positive relationship between job relevant information on job performance. The high job relevant information held by the manager will function as a facilitator for decision making that will increase job performance. Murray (1990) suggests that job relevant information can improve managerial performance. This happens because from the information provided by the subordinates will get a better or more appropriate budget level for the company and the boss can develop a better strategy, which can be submitted to subordinates so that performance increases. Halim and Devie (2013), Tapatfeto (2012), Lopez et al. (2007), Chong and Chong (2002) show that job relevant information is able to improve performance, because it provides accurate predictions of environmental conditions and also provides input in selecting appropriate actions.

Surya and Devie (2013) who conduct research in the manufacturing sector want to see the influence of budget participation on managerial performance through job relevant information as a mediating variable. The results illustrate that job relevant information mediates the relation between budget participation and job performance from company managers who are the object of research. Kren (1992) provides evidence that task-related information has a positive influence on performance. Kren (1992) also uses job relevant information as a mediating variable to the relationship of budget participation with managerial performance. The results show that job relevant information is able to mediate the relationship between budget participation and managerial performance. From the previous discussion, the hypotheses that can be obtained are:

$\mathrm{H} 2$ : job relevant information mediates the influence of budget participation against job performance.

\section{RESEARCH MODEL}

Based on the theoretical framework discussed earlier, a conceptual framework is arranged as shown in Figure 1.

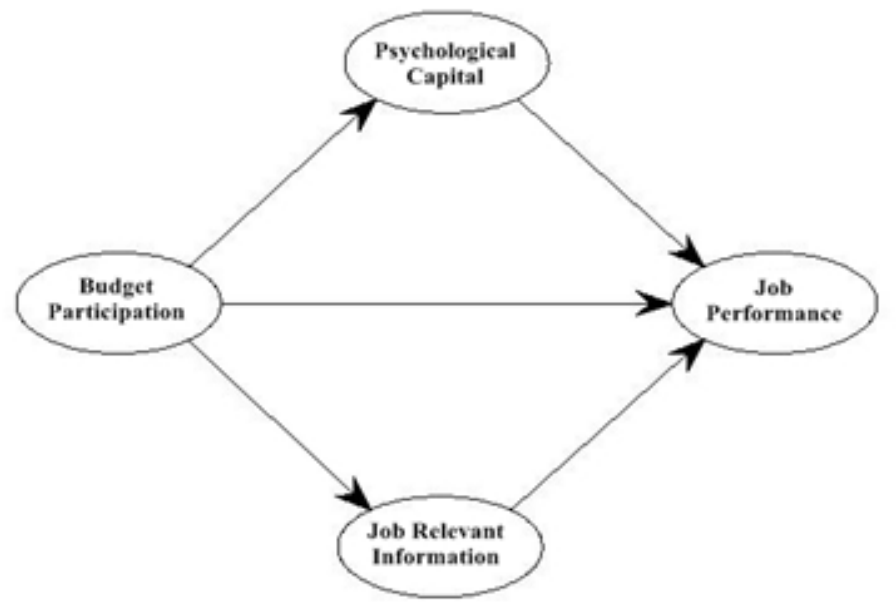

Figure1. Conceptual Framework of Research

\section{RESEARCH METHOD}

\subsection{Research Design}

This study was designed using quantitative methods. Quantitative method is focused on testing empirically: (1) impact psychological capital mediation on the influence of budget participation on job performance, and (2) the impact of mediating job relevant information on the influence of budget participation on job performance. 


\subsection{Population and Sample}

The population of this research is Civil Servants (PNS) who occupy structural positions echelon II and III in the East Java Province Regional Apparatus. Based on data from the East Java Provincial Personnel Board as of December 2017, the number of civil servants who held structural positions echelon II and III at East Java Province Regional Apparatus is 573 people. Next, the researcher determines the number of research samples using the Slovin formula so that the minimum sample size of the study is 236. The researcher then uses the sampling technique with purposive sampling, namely the researcher determines the sample taken because of certain concerns (Sugiyono, 2013), namely the civil servant who occupies structural positions of echelon II and III.

\subsection{Variable Measurement}

Variables on this research is a budget participation, psychological capital, job relevant information, and job performance. Budget participation is how broadly individuals are involved and have an influence in budgeting (Brownell, 1982). To assess budget participation, six statement instruments were adopted from Milani's (1975) research, which included: manager involvement in the budget preparation process; reason of supervisor in revising the proposed budget; frequency of giving advice and opinions; influence of managers in the final budget; the importance of the contribution given; and frequency of opinion requests. Every indicator of budget participation measured by a 5-point Likert scale measurement unit.

Psychological capital is defined as the state of progress of a person's positive and characterized by (Luthans et al., 2007): (1) have the confidence (self-efficacy) to face the tasks are challenging and give enough effort to succeed in these tasks; (2) do not easily give up in achieving goals and if necessary find a way to achieve goals ( hope ); (3) making positive attribution (optimism) about success in the present and the future; and (4) when faced with problems and obstacles can survive and return (resiliency). According to Luthans et al. (2007) to measure the level of psychological capital, a PsyCap (PCQ) questionnaire was used which consisted of 24 statement items, each of which consisted of 6 statement items. Respondents were asked to provide an assessment by selecting one of the five points of the Likert scale provided.

Job relevant information is defined as how many managers in this case echelon II and III structural officials in East Java Province Regional Apparatus have the appropriate information or related to the tasks that they do. Job relevant information in this study is referred to as a mediating variable, measured by how well officials know what to do, have sufficient information to make optimal decisions, and are able to obtain strategic information needed as an alternative in decision making. The research instrument used to measure this variable consists of 3 (three) items statements from Kren (1992). Measurement of this variable uses a statement with a Likert scale of 1 (one) to 5 (five).

Job performance is the manager's performance in managerial activities which include planning, investigating, coordinating, evaluating, supervising, staffing, negotiating, representing and overall performance (Mahoney et al., 1965). Job performance in this study is called the dependent variable. This variable is measured using an instrument self-rating from Mahoney et al. (1965). Respondents were asked to provide an assessment by selecting one of the five points of the Likert scale provided. The self-rating approach in job performance measurement is chosen to avoid the possibility of unrepresentative job performance measurement, because if the superior rating is used there is a possibility that the superior does not understand the actual conditions (Heneman, 1974; Nazaruddinet al., 2003).

\subsection{Method of Collecting Data}

Data collection method used in this study is a questionnaire method. The research questionnaire consists of two main parts. The first part is self-identity that describes the characteristics of respondents. The second part is the measurement of operational variables that contain a series of questions to measure research variables. The data collection will be done by direct distribution method, which went to the respondents directly to submit or collect back the questionnaire.

\subsection{Data Analysis Technique}

Data analysis techniques in this study using Structural Equation Modeling-Partial Least Square with the help of WarpPLS version 5.0 software. The SEM-PLS model is used in this study because it is 
seen in accordance with the character of the research, specifically: (1) the model can be estimated by the sample size not to be large; (2) does not require data distribution because this model is nonparametric; and (3) this model can work on metric and ordinal scales (Sholihin and Ratmono, 2013). PLS can be used as a confirmation of theory and can also be used to recommend existing relationships or not and also propose further testing propositions (Ghozali, 2006).

\section{ANAlysis AND DiscuSsion}

\subsection{Profile and Descriptive Respondents}

Respondents in this study were public sector managers namely echelon II and III structural officials in the East Java Province Regional Apparatus. The sample target in this study is 236 samples. The questionnaire distributed by the researcher exceeds the number of research samples, namely 293 questionnaires. This is done by researchers to increase the number of questionnaires that can later be processed. Of the 293 questionnaires distributed, 128 samples were received again by the researcher. While the remaining 165 samples were not received by the researcher because until the time limit was determined, the respondent did not return the results of filling out the questionnaire to the researcher. The total sample that returned and fulfilled the eligibility requirements to be processed and analyzed further was 112. The number of samples still fulfilled the provisions of said representative sample size as suggested by Ferdinand (2014) and Ghozali (2014), namely as many as 100 to 200 samples.

Profile of the respondent which includes length of service, education, years of service, and involvement in preparing the budget. The majority of the 112 respondents, serving for 1 to 3 years (35.7\%), with Master education background (87.5\%) and over 25 years of service (59.8\%) and were frequently involved in the preparation of the budget $(49,1 \%)$.

\subsection{Budget Participation}

Variable data budget participation (BP) is obtained from the questionnaire with 6 (six) statement items. Table 1 shows that descript respondents on budget participation variables obtained an average value of 4.11 which is classified in the high category. This shows that the level of participation of public sector managers in the budget preparation process is high.

Table1. Budget Participation

\begin{tabular}{|l|l|l|}
\hline \multicolumn{1}{|c|}{ Indicator } & \multicolumn{1}{c|}{ Category } \\
\hline BP1 & 4.36 & Very high \\
\hline BP2 & 4.29 & High \\
\hline BP3 & 4.09 & High \\
\hline BP4 & 3.83 & High \\
\hline BP5 & 4.07 & High \\
\hline BP6 BP & 4.04 & High \\
\hline & $\mathbf{4 . 1 1}$ & High \\
\hline
\end{tabular}

\subsection{Psychological Capital}

Variable data psychological capital (PC) obtained from the questionnaire with 24(twentyfour) statement items. Table 2 shows that the description of the respondent's answer to the psychological capital variable obtained an average value of 4.00 classified as high. This shows that the level of psychological capital public sector managers is high.

Table2. Psychological Capital

\begin{tabular}{|c|l|l|l|l|l|}
\hline Indicator & \multicolumn{1}{|c|}{ Mean } & \multicolumn{1}{|c|}{ Category } & Indicator & \multicolumn{1}{|c|}{ Mean } & \multicolumn{1}{c|}{ Category } \\
\hline PC1 & 4.05 & High & PC13 & 4.08 & High \\
\hline PC2 & 4.19 & High & PC14 & 3.62 & High \\
\hline PC3 & 4.15 & High & PC15 & 4.07 & High \\
\hline PC4 & 4.14 & High & PC16 & 4.21 & Very high \\
\hline PC5 & 4.01 & High & PC17 & 3.80 & High \\
\hline PC6 & 4.28 & Very high & PC18 & 4.21 & Very high \\
\hline PC7 & 4.04 & High & PC19 & 4.06 & High \\
\hline PC8 & 4.37 & Very high & PC20 & 3.97 & High \\
\hline PC9 & 4.27 & Very high & PC21 & 3.62 & High \\
\hline
\end{tabular}


The Mediating Impact of Psychological Capital and Job Relevant Information on the Influence of Budget Participation against Job Performance

\begin{tabular}{|l|l|l|l|l|l|}
\hline PC10 & 3.79 & High & PC22 & 3.68 & High \\
\hline PC11 & 4.26 & Very high & PC23 & 3.94 & High \\
\hline PC12 & 3.37 & High enough & PC24 & 3.79 & High \\
\hline \multicolumn{7}{|l|}{ PC } & $\mathbf{4 . 0 0}$ & High \\
\hline
\end{tabular}

\subsection{Job Relevant Information}

Variable data job relevant information (JRI) obtained from a questionnaire with 3 (three) statement items. Table 3 shows that the description of the respondent's answer to the variable job relevant information obtained an average value of 4.01 classified as high. This shows that the level of job relevant information Public sector managers is high.

Table3. Job Relevant Information

\begin{tabular}{|l|l|l|}
\hline \multicolumn{1}{|c|}{ Indicator } & \multicolumn{1}{c|}{ Mean } & \multicolumn{1}{c|}{ Category } \\
\hline JRI1 & 4.04 & High \\
\hline JRI2 & 4.02 & High \\
\hline JRI3 & 3.97 & High \\
\hline & $\mathbf{4 . 0 1}$ & High \\
\hline
\end{tabular}

\subsection{Job Performance}

Variable data job performance (JP) obtained from the questionnaire with 9 (nine) statement items. Table 4 shows that descript of respondents on job variables performance an average value of 4.01 classified as high. This shows that the level of job performance public sector managers is high.

Table4. Job Performance

\begin{tabular}{|l|l|l|}
\hline Indicator & \multicolumn{1}{|c|}{ Mean } & \multicolumn{1}{c|}{ Category } \\
\hline JP1 & 4.09 & High \\
\hline JP2 & 4.07 & High \\
\hline JP3 & 4.01 & High \\
\hline JP4 & 4.14 & High \\
\hline JP5 & 4.30 & Very high \\
\hline JP6 & 4.07 & High \\
\hline JP7 & 3.51 & High \\
\hline JP8 & 3.90 & High \\
\hline JP9 & 4.02 & High \\
\hline & $\mathbf{4 . 0 1}$ & High \\
\hline
\end{tabular}

\subsection{Evaluation of Measurement Models}

Evaluation of measurement models is carried out to assess the validity and reliability of construct indicators. Convergent validity at the construct level is evaluated by looking at the average variance value extracted (AVE). An internal consistency test can be determined by the Cronbach's Alpha coefficient (Sholihin and Ratmono, 2013).

Validity and reliability test result indicate that there are 14 indicators variables are invalid, that were PC5, PC7, PC10, PC12, PC13, PC14, PC15, PC17, PC18, PC19, PC20, PC21, PC22 and PC24. Researchers removed one indicator of JP7 research variables to solve the problem of validity and reliability of research data. The test results indicate that both the validity of the entire value of factor loading above 0.40 with composite reliability value for every variable research above 0.70 and AVE in a purse value of 0.50 . Show reliability test results that the entire value of Cronbach's Alpha above 0.70 which shows that all research variables are reliable. Thus, research data can be used to test the research hypothesis because it is valid and reliable.

The second evaluation on the outer model is discriminant validity. Discriminant validity test is used to determine the correlation between indicators with all existing latent variables. The discriminant validity test was assessed from cross loading measurement with its construct. It is declared valid, if an indicator has the highest loading factor in the intended construct compared to loading factor to another construct. In this study, indicators of latent variables have met the criteria of discriminant validity. Loading factor for each indicator in a construct is greater than the value of cross loading indicator in another construct. 


\subsection{Structural Model Evaluation}

Structural models are evaluated by looking at the magnitude of $\mathrm{R}^{2}$ which reflects the percentage of variance in latent variables that are explained by latent variables that are thought to influence (Kock, 2013). Evaluate the next structural model by looking at $\mathrm{Q}^{2}$ which shows the level of predictive relevance of the research model (Ghozali and Latan, 2014). The value of $Q^{2}>0$ indicates that the model has predictive relevance, while $\mathrm{Q}^{2}<0$ indicates that the model lacks predictive relevance (Ghozali and Latan, 2014). Here in the mentioned evaluation of the structural model.

Table5. Evaluation of Structural Models

\begin{tabular}{|l|c|c|c|}
\hline \multirow{2}{*}{\multicolumn{1}{|c|}{ Information }} & \multicolumn{3}{|c|}{ Endogenous variable } \\
\cline { 2 - 4 } & PC & JRI & JP \\
\hline R-square coefficients & 0.409 & 0.278 & 0.625 \\
\hline Q-squared coefficients & 0.410 & 0.277 & 0.628 \\
\hline
\end{tabular}

Based on the evaluation of the structural model, the determination coefficient of R-square gives a value of 0.625 for job performance variables, which means that budget participation, psychological capital, and job relevant information capable of explaining the variance job performance by $62,5 \%$, while the remaining $37.5 \%$ is explained by other factors that are not in the model. Psychological capital has the R-square value of 0.409 , which means that the variance of psychological capital budget can be explained by the participation of $40.9 \%$, while the remaining $59.1 \%$ is explained by other factors that are not in the model. Job relevant information has a value of 0.278 which means that the variance of job relevant information can be explained by the budget participation of $27.8 \%$, the rest is explained by other factors outside the model by $72.2 \%$. Thus, it can be concluded that there are still other factors outside the model that need to be considered related to factors that influence the phenomenon of job performance in the public sector.

The results of the Q-square calculation in this study indicate that the value of $\mathrm{Q}^{2}$ both endogen psychological capital variables, job relevant information, and job performance is above $0\left(Q^{2}>0\right)$ which indicates that exogenous variables have good predictive relevance to endogenous variables.

\subsection{Hypothesis Test}

Testing of the proposed hypothesis can be seen from the estimation of coefficient of determination $\left(R^{2}\right)$ with a beta coefficient $(\beta)$ and the p-value. The value of $\beta$ is valued according to the direction of the hypothesis relationship and the p-value is $<5 \%$. The estimation results can be seen in the following figure:

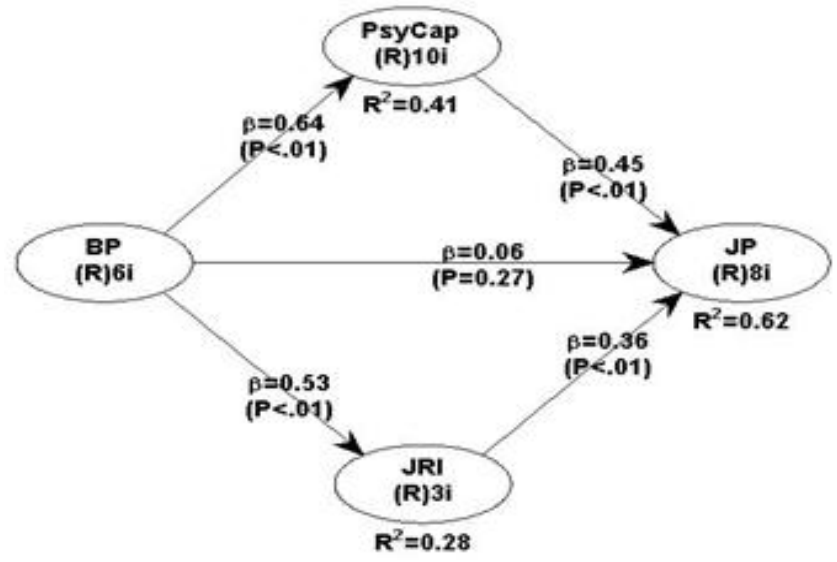

Figure2. PsyCap and JRI Mediation on BP's Influence on JP

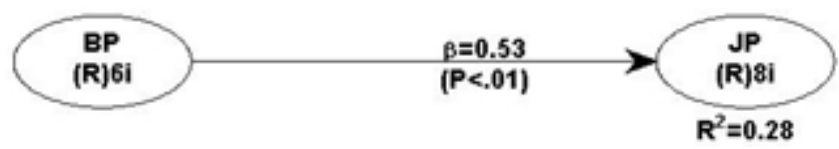

Figure3. $B P^{\prime}$ s direct influence on $J P$ 


\subsubsection{Test of hypothesis1: Psychological Capital Mediates the Effect of Budget Participation on Job Performance}

The results of the mediation effect test in Figure 2 shows that the influence of budget participation on psychological capital has a value of $\beta$ of 0.64 and a significant $p$ value $(0.01<0.05)$, the effect of psychological capital on job performance has a value of $\beta$ of 0.45 and a significant $p$ value $(0.01<0.05)$. while the influence of budget participation on job performance has a $\beta$ value of0.06 and $p$ value is not significant (0.27>0.05). Decrease in $\beta$ value (from 0.53 to 0.06 ) and $p$ value that is not significant occurs in the influence of budget participation on job performance after entering the psychological capital mediation variable. Thus, it can be said that psychological capital fully mediates influence budget participation on job performance because the influence of independent variables on mediating variables and the influence of mediating variables on the dependent variable is significant, but the influence of the independent variable on the dependent variable decreases and is not significant. This indicates that the mediation of psychological capital in the form of mediation full. Based on this, it can be concluded that the psychological capital hypothesis mediates the effect of budget participation on job performance can be supported.

\subsubsection{Test of hypothesis 2: Job Relevant Information Mediates the Effect of Budget Participation on Job Performance}

Based figure 2, known that the effect of budget participation on the job relevant information has a $\beta$ value of 0.53 and a p-value significantly $(0: 01<0.05)$, the effect of job relevant information on job performance has a $\beta$ value of 0.36 and a p-value significantly $(0.01<0.05)$. While the effect of budget participation on job performance has a $\beta$ value of 0.06 and $p$ value not significant $(0: 27>0.05)$. The decline in the value of $\beta$ (of 0.53 to 0.06 ) and $p$ value were not significantly occurred on the influence of budget participation on job performance after inserted mediating variables job relevant information. Thus, it can be concluded that job relevant information fully mediates the influence of budget participation on job performance because the influence of the independent variable on the mediating variable and the influence of the mediating variable on the dependent variable is significant, but the influence of the independent variable on the dependent variable decreases and is not significant. This indicates that the mediation job relevant information in the form of mediation full. These results support the hypothesis that job relevant information mediates the effect of budget participation on job performance.

\section{DISCUSSION}

Hypothesis 1 which states that psychological capital mediates the influence of budget participation on job performance can be proven in this study. Thus, higher level of employee involvement in the process of drafting a budget will have the high psychological capital. This positive psychological behavior will ultimately improve the performance of the employee.

The estimation results in this study are not in accordance with the theory of goal setting. Goal setting theory which states that the performance of people who participate in formulating goals is better than those who do not participate (Locke and Latham, 2002). The estimation results in this study are also not in accordance with the research of Abata (2014), Karsam (2013), Indarto and Ayu (2011), Eker (2008), Nouri and Parker (1998) who found a significant positive relationship between budget participation and job performance.

Contingency theory explains that there is no control system universally always appropriate to be applied to the whole organization in every circumstance. The role of psychological capital as an intermediary influences of budget participation on job performance can be explained through a contingency approach, namely the influence of budget participation on job performance also depends on situational factors that act as mediation. The results of this study indicate that psychological capital as situational factors are able to fully mediate the influence of budget participation on job performance. Increasing job performance cannot be done with budget participation, but it must be through psychological capital.

This research has proven that budget participation has a positive and significant effect on psychological capital. This is in accordance with the opinion of Nuryaniet al. (2018), Ulfaet al. 
(2017), Lina (2015), Solehaet al. (2014). This research managed to prove the effect of psychological capital to job performance. This is consistent with Falah's (2018) study, Durrahet al. (2016), Saithongin and Ussahawanitchakit (2016), Liwarto and Kurniawan (2015), Kappagodaet al. (2014), Luthanset al. (2008), Luthanset al. (2005) which states that psychological capital has a significant effect on job performance. The results of the estimation of the first hypothesis in this study are in line with the research of Venkatesh and Blaskovich (2012). Manager of the public sector should be paying close attention to their involvement in budget participation because it would make the psychological capital was in him to rise, organizations need to invest in an increase in psychological capital managers, so that they are in the work can improve job performance.

Hypothesis 2 which states that job relevant information mediates the influence of budget participation on job performance can be proven in this study. The higher the budget participation of public sector managers, the more relevant job relevant information is. This then has an impact on increasing job performance.

The estimation results in this study are not in accordance with goal setting theory. Goal setting theory states that the performance of the people who participated in formulating the purpose better than those who did not participate (Locke and Latham, 2002). The estimation results in this study are also not in accordance with the research of Oluwalope and Sunday (2017), Hariyantiet al. (2015), Setyarini and Susty (2014), Ulupui (2005), Brownell and McInnes (1986) who found a significant positive relationship between budget participation and job performance.

The role of job relevant information as an intermediary influencing the budget participation of job performance can be explained through a contingency approach, namely that the influence of budget participation on job performance also depends on situational factors that act as mediation where these factors are specific and not solely caused by involvement managers in budget participation. These results indicate that the job relevant information as factors situational able to mediate the full relationship budget participation towards job performance. Increasing job performance cannot be with budget participation but must be through job relevant information.

This research has proven that budget participation has a positive and significant effect on job relevant information. This is consistent with the opinion of Nengsyet al. (2013), Pongawa and Devie (2013), Lopez et al. (2009), Heath and Brown (2007), Lau and Tan (2003). This research succeeds to prove the influence of job relevant information on job performance. This is consistent with the research of Halim and Devie (2013), Tapatfeto (2012), Eker (2008), Lopez et al. (2007), Chong and Chong (2002) which state that job relevant information take effect significant to job performance. The estimation results of the second hypothesis in this study are in accordance with Kren's (1992) study. It is imperative to apply the budget participation in public sector managers, because the positive effects will increase job relevant information, job relevant information is high, will have a positive impact also on enhancing the job performance.

\section{CONCLUSIONS AND RECOMMENDATIONS}

From the results of this study can be concluded as follows:

- Psychological capital is able to fully mediate the influence of budget participation to job performance. This full form of mediation shows that the higher the level of budget participation of public sector managers will increase the level of psychological capital. This positive psychology behavior will ultimately increase job performance.

- Job relevant information is also able to fully mediate the influence of budget participation on job performance. This shows that the higher the public-sector manager's budget participation, the more relevant job relevant information he has. The use of job relevant information that high at last job performance manager will increase.

From the results of this study can be suggested as follows:

- Future research should expand the area of research in the scope of provincial governments throughout Java or even Indonesia. Mix from elements of the central, provincial, district and city governments to get mo+re generalizable results can also be considered. 
- Future research can use mediating variables other than psychological capital and job relevant information.

This study is limited to using questionnaire media to obtain primary data so that it relies on the level of respondents' perception so that subjectivity factors can be contained in it. The research simulation is limited to the East Java Provincial Government. Limitation The resulting estimation can only be generalized in East Java Provincial Government itself. This is a limitation of generalization because every government agency has different employee characteristics that allow different results.

This study reconfirms the results of previous studies concerning the variables of psychological capital and job relevant information as mediating variables on the influence of budget participation on job performance. This study provides additional literature related to job performance organization public-sector. Giving an input to the practice of budget participation in the government sector in order to improve job performance and usage psychological capital and job relevant information as a means to improve the psychological condition of employees, a means to obtain information that supports decision making. Giving an inspiration for subsequent studies.

\section{REFERENCES}

[1] Karsam. 2013. The Influence of Participation in Budgeting on Budgetary Slack with Information Asymmetry as a Moderating Variable and Its Impact on the Managerial Performance (A Study on Yayasan Pendidikandan Koperasi in the Province of Banten, Indonesia). International Journal of Business Studies and Applied Finance. Vol. 1. pp. 28-38.

[2] Brownell, P. 1982. The Role Of Accounting Data in Performance Evaluation, Budgetary Participation, and Organizational-Effectiveness. Journal of Accounting Research. Vol. 20. pp. 12-27.

[3] Govindarajan, Vijay. 1986. Impact of Participation in The Budgetary Process on Managerial Attitudes and Performance: Universalistic and Contingency Perspectives. Decision Sciences. Vol. 17. pp. 496-516.

[4] Stoner, James Arthur Finch and R. Edward Freeman. 1992. Management. 5th ed. England: Englewood Cliffs N.J Prentice Hall.

[5] Kren, L. 1992. Budgetary Participation and Managerial Performance: The Impact of Information and Environmental Volatility. The Accounting Review. Vol. 67. pp. 511-526.

[6] Covaleski, M. A., J. H. Evans, J. H. Luft, and M. D. Shields. 2003. Budgeting research: Three Theoretical Perspectives and Criteria for Selective Integration. Journal of Management Accounting Research. Vol. 15. pp. 3-49.

[7] Heath, Rebekah Sheely and James F. Brown. 2007. A Re-examination of The Effect of Job-Relevant Information on The Budget Participation-Job Participation Relation During an Age of Employee Empowerment. Journal of Applied Business Research. Vol. 23. pp. 111-124.

[8] Venkatesh, Roopa and Jennifer Blaskovich. 2012. The Mediating Effect of Psychological Capital on the Budget Participation-Job Performance Relationship. Journal of Management Accounting Research. Vol. 24. pp. 159-175.

[9] Chong, V. K. and K. M. Chong. 2002. Budget Goal Commitment and Informational Effects of Budget Participation on Performance: A Structural Equation Modeling Approach. Behavioral Research in Accounting. Vol. 14.pp. 65-86.

[10] Luthans, F., S. M. Norman, B. J. Avolio, and J. B. Avey. 2008. The Mediating Role of Psychological Capital in The Supportive Organizational Climate- Employee Performance Relationship. Journal of Organizational Behavior. Vol. 29. pp. 219-238.

[11] Sinuraya, Candra. 2009. Pengaruh Partisipasi Penyusunan Anggaranterhadap Kinerja Manajer: Peran Kecukupan Anggarandan Job Relevant Information sebagai Variable Intervening. Jurnal Akuntansi. Vol 1. pp. 17-39.

[12] Locke, E. A. and Bryan, J. 1968. Goal Setting As a Determinant of The Effect of Knowledge of Score in Performance. The American Journal of Psychologist. Vol 81. pp. 398-406.

[13] Locke, E. A. and Latham, G. P. 2002. Building A Practically Useful Theory Of Goal Setting And Task Motivation: A 35 - Year Odyssey. American Psychologist. Vol. 57. pp. 705-717.

[14] Sisaye, Seleshi. 1998. Contingencies Influencing The Effectiveness of Acquisition-Based Corporate Growth and Development Strategies: The Case of ITT, 1920-1997. Leadership \& Organization Development Journal. Vol. 19. pp. 231-255. 
[15] Nouri, H. and P. Parker. 1998. The Relationship Between Budget Participation and Job Performance: The Roles of Budget Adequacy and Organizational Commitment. Accounting, Organizations, and Society. Vol. 23. pp. 467-483.

[16] Indarto, Stefani Lily danStephanaDyahAyu. 2011. Pengaruh Partisipasidalam Penyusunan Anggaranterha dapKinerja Manajerial Perusahaan melalui Kecukupan Anggaran, Komitmen Organisasi, Komitmen Tujuan Anggaran, dan Job Relevant Information (JRI). Seri KajianIlmiah. Vol. 14. pp. 1-44.

[17] Abata, Matthew A. 2014. Participative Budgeting and Managerial Performance in The Nigerian Food Products Sector. Global Journal of Contemporary Research in Accounting, Auditing, and Business Ethics. Vol. 1. pp. 148-167.

[18] Oluwalope, AdenugaAbiola and Ojediran Sunday. 2017. Impact of Budgetary Participation and Organizational Commitment on Managerial Performance in Nigeria. Accounting and Finance Research. Vol. 6. pp. 48-55.

[19] Ulupui, I. G. K. 2005. Pengaruh PartisipasiAnggaran, PersepsiKeadilanDistributif, KeadilanProsedural, dan Goal Commitment terhadapKinerjaDinas. Kinerja. Vol. 9. pp. 98-112.

[20] Milani, K. 1975. The Relationship of Participation in Budget Setting to Industrial Supervisor Performance and Attitudes: A Field Study. The Accounting Review. Vol. 50. pp. 274-284.

[21] Syahputra, Zubir. 2014. Budget Participation on Managerial Performance: Related Factors in that influenced to Government's Employee (Study of Indonesian Local Government). Journal of Economics and Sustainable Development. Vol 5. pp. 95-99.

[22] Nuryani, Yuni, SyaikhulFallah, dan Bill J.C. Pangayow. 2018. PengaruhPartisipasiAnggaranterhadap Budgetary Slack dengan Psychological Capital sebagaiVariabel Intervening (Studi Empirispada Rumah Sakit di Kota Jayapura). JurnalAkuntansi\&Keuangan Daerah. Vol. 13. pp. 38-52.

[23] Lina. 2015. Partisipasi Penyusunan Anggaran, Psychological Capital, danKinerja Manajerial. Jurnal Manajemen Teknologi. Vol. 14. pp. 301-320.

[24] Soleha, Nurhayati, Rita Rosiana, danAgusSholikhanYulianto. 2014. PengaruhMediasi Modal PsikologispadaHubungan Model PerencanaanAnggarandanKinerjaPegawai (StudiEmpirispada PNS PemerintahProvinsiBanten). JurnalAkuntansi. Vol. 18. pp. 188-201.

[25] Durrah O., Alhamoud, A. and Khan, K. 2016. Positive Psychological Capital and Job Performance: The Mediating Role of Job Satisfaction. International Scientific Researches Journal. Vol. 72. pp. 1-15.

[26] Falah, Syaikhul. 2018. Pengaruh Creative Psychology Capital Memediasi Sensitivitas Etisterhadap Job Performance. JurnalKajianEkonomidanKeuangan Daerah. Vol. 3. pp. 58-81.

[27] Saithong-in, Supapan and PhaprukbarameeUssahawanitchakit. 2016. Psychological Capital and Job Performance: an Empirical Research of Certified Public Accountants (CPAs) in Thailand. The Business and Management Review. Vol. 7. pp. 499-506.

[28] Luthans, F., B. J. Avolio, F. O. Walumbwa, and W. Li. (2005). The Psychological Capital of Chinese Workers: Exploring the Relationship with Performance. Management and Organization Review. Vol. 1. pp. 247-269.

[29] Liwarto, Iwan Hanafi dan Kurniawan Albert. 2015. Hubungan Psycap dengan Kinerja KaryawanPT.X Bandung. Jurnal Manajemen. Vol.14. pp. 223-244.

[30] Ulfa, PutriRizkya, MirnaIndriani, dan Said Musnadi. 2017. EfekMediasi Positive Psychological Capital dalamHubunganantaraPartisipasiPenyusunanAnggarandenganKinerjaManajerialBadan Usaha Milik Daerah (BUMD) Provinsi Aceh. JurnalMegisterAkuntansiPascasarjanaUniversitasSyiah Kuala. Vol. 6. pp. 43-48.

[31] Brownell, P. and M. McInnes. 1986. Budgetary Participation, Motivation, and Managerial Performance. The Accounting Review. Vol. 61. pp. 587-600.

[32] Hariyanti, Widi, PupungPurnamasari, and MagnazLestira O. 2015. Pluriform Motivation As Antecedent and Its Relationships to Budgeting Participation and Managerial Performance (Empirical Study on Manufacturing Companieslisted on Indonesian Stock Exchange). Procedia - Social and Behavioral Sciences. Vol 211. pp. 836-843.

[33] Setyarini, Maria Nikendan Anastasia Susty. 2014. Pengaruh Partisipasi Anggaranterhadap Kinerja Manajerialdengan Komitmen OrganisasisebagaiVariabel Intervening. Modus. Vol. 26. pp. 63-76.

[34] Brownell, P. and Hirst, M. 1986. Reliance on Accounting Information, Budgetary Participation, and Task Uncertanity: Tests of A Three Way Interaction. Journal of Accounting Research. Vol. 24. pp. 241-249.

[35] Nengsy, Herda, Ria Nelly Sari, danRestuAgusti. 2013. Pengaruh Partisipasi Penyusunan Anggaran TerhadapKinerjaManajerialdengan Job Relevant Information, KepuasanKerjadanMotivasiSebagaiVariabel Intervening. JurnalAkuntansi. Vol. 2. pp. 1-17. 
[36] Pongawa, ViliantydanDevie. 2013. Pengaruh Budgeting Participation terhadap Job Satisfaction padaSektorManufaktur di Surabaya. Business Accounting Review. Vol. 1. pp.95-109.

[37] Lau, C.M. and Tan, S.L.C. 2003. The Effects of Participation and Job Relevant Information on The Relationship between Evaluative Style and Job Satisfaction. Review of Quantitative Finance and Accounting. Vol. 17. pp. 17-34.

[38] Eker, Melek. 2008. The Affect of The Relationship between Budget Participation and Job Relevant Information on Managerial Performance. Age Academic Review. Vol. 8. pp. 183-198.

[39] Lopez, Maria A. Leach, William W. Stammerjohan, and Kyoo Sang Lee. 2009. Budget Participation and Job Performance of South Korean Managers Mediated by Job Satisfaction and Job Relevant Information. Management Research News. Vol. 32. pp. 220-238.

[40] Murray, D. 1990. The Performance Effects of Participative Budgeting: An Integration of Intervening and Moderating Variables. Behavioral Research in Accounting. Vol. 2. pp. 104-123.

[41] Halim, RiaNovitadanDevie. 2013. Pengaruh Budgeting Participation terhadap Managerial Performance padaSektorJasa di Surabaya. Business Accounting Review. Vol. 1. Pp. 82-94.

[42] Tapatfeto, JasinthaDessy. 2012. Job Relevant Information Desentralisasidan Partisipasi Anggaranterhadap Kinerja Manajerial. Jurnal EkonomidanKeuangan. Vol. 1. Pp. 219-241.

[43] Lopez, Leach, M.A., Stammerjohan, W.W. and McNair, F.M. 2007. Differences In The Role Of Job Relevant Information In The Budget Participation-Performance Relationship Among USA and Mexican Managers: A Question of Culture or Communication?.Journal of Management Accounting Research. Vol. 19. pp. 105-36.

[44] Surya, Daniel danDevie. 2013. Pengaruh Budgeting Participation terhadapManagarial Performance padaSektorManufaktur. Business Accounting Review. Vol. 1. pp. 151-160.

[45] Sugiyono.2013. Metode Penelitian Kuantitatif, Kualitatif, dan R \& D.Bandung: Alfabeta.

[46] Mahoney, T. A., T. H. Jerdee, and S. J. Carroll. 1965. The Job(s) of Management. Industrial Relations: Industrial Relations. Vol. 4. pp. 97-110.

[47] Heneman, H. G. 1974. Comparisons of Self and Superior Ratings of Managerial. Performance. Journal of Applied Psycology. Vol. 59. pp. 638-642.

[48] Nazaruddin, Ietje, ErniSuryandari, dan Barbara Gunawan. 2003. Desentralisasi, Sistem Pengendalian Akuntansidan KinerjaOrganisasi (StudiEmpirispadaOrganisasiSektorPublikPropinsi Daerah Istimewa Yogyakarta). JurnalAkuntansidanInvestasi. Vol. 4. pp. 77-97.

[49] Sholihin, M. danRatmono D. 2013. Analisis SEM PLS dengan Warp PLS untukHubungan Non Linier dalamPenelitianSosialdanBisnis. Yogyakarta: PenerbitAndi.

[50] Ghozali, Imam. 2006. Structural Equation Modeling MetodeAlternatifdengan Partial Least Square (PLS). Semarang: BadanPenerbitUniversitasDiponegoro.

[51] Ferdinand, Augusty. 2014. Structural Equation Modeling dalamPenelitianManajemen: Aplikasi ModelModel RumitdalamPenelitianuntukSkripsi, Tesis Magister danDisertasiDoktor. Semarang: Badan Penerbit Universitas Diponegoro.

[52] Ghozali, Imam. 2014. Structural Equation Modeling, MetodeAlternatifdengan Partial Least Square (PLS). Semarang: BadanPenerbitUniversitasDiponegoro.

[53] Kock, Ned. 2013. WarpPLS 4.0 User Manual. Laredo Texas, USA: ScriptWarp Systems.

[54] Ghozali, Imam danHengkyLatan. 2014. Partial Least Squares. Konsep, Metode, danAplikasiMenggunakan Program WarpPLS 4.0. Semarang: BadanPenerbitUniversitasDiponegoro.

[55] Luthans, F., C. M. Youssef, and B. J. Avolio. 2007. Psychological Capital: Developing the Human Competitive Edge. Oxford UK: Oxford University Press.

[56] Kappagoda, U. S., HohdZainulFithri Othman, and Gamini De Alwis. 2014. Psychological Capital and Job Performance: The Mediating Role of Work Attitudes. Journal of Human Resource and Sustainability Studies. Vol. 2. pp. 102-116.

\section{AUTHORS' BIOGRAPHY}

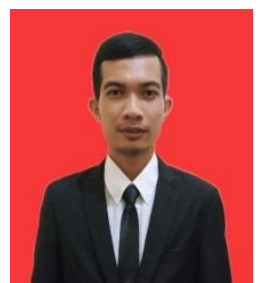

IkhlasUl Aqmal earned his Bachelor's degree from Department of Accounting Education, Makassar State University in 2014 and later his Master's Degree in Accounting from Department of Magister Accounting, Airlangga University in 2018. 


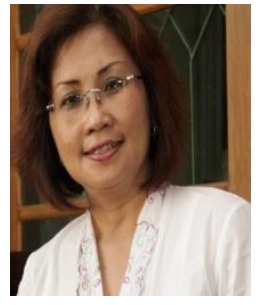

Noorlailie Soewarno earned her Bachelor's degree in University of Indonesia in 1987, her Master of Business Administration in Western Carolina University in 1991, and later her Doctor's degree in Airlangga University in 2004. Currently she is a lecturer at Airlangga University and she can be reached through

Citation: Ikhlas Ul Aqmal, Noorlailie Soewarno. "The Mediating Impact of Psychological Capital and Job Relevant Information on the Influence of Budget Participation against Job Performance". International Journal of Managerial Studies and Research (IJMSR), vol 6, no. 11, 2018, pp. 1-14. doi: http://dx.doi.org/10.20431/2349-0349.0611001.

Copyright: (C) 2018 Authors. This is an open-access article distributed under the terms of the Creative Commons Attribution License, which permits unrestricted use, distribution, and reproduction in any medium, provided the original author and source are credited. 